\title{
Correction to: Developing an Empirical Summation Chart on the Distribution of Extension Fractures in Matured Yielding Pillars Using Geophysical Technique and an Optical Instrument
}

\author{
Fhatuwani Sengani ${ }^{1}$ (D)
}

Published online: 5 August 2021

(c) Society for Mining, Metallurgy \& Exploration Inc. 2021

\section{Correction to: Mining, Metallurgy \& Exploration}

https://doi.org/10.1007/s42461-021-00459-y

Due to a Production error, in the original online publication of this article the wrong image was used for Table 2 . The article has been revised and it is now correct.

Publisher's Note Springer Nature remains neutral with regard to jurisdictional claims in published maps and institutional affiliations.

The original article can be found online at https://doi.org/10.1007/ s42461-021-00459-y.

Fhatuwani Sengani

fhatugeorge@gmail.com; fhatuwani.sengani@ul.ac.za

1 Department of Geology and Mining, Physical and Mineral

Sciences, University of Limpopo, Private Bag X1106,

Sovenga 0727, Limpopo Province, South Africa 